\title{
scripted
}

Volume 12, Issue 2, December 2015

\section{NEWS FROM SCRIPTED}

Laura Downey* \& Catriona McMillan*

DOI: $10.2966 /$ scrip. 120215.78

\section{(c) (i) $(9)$} under a Creative Commons Attribution-NonCommercial-ShareAlike 4.0 International License. Please click on the link to read the terms and conditions.

${ }^{*}$ Editor-in-Chief, SCRIPTed. PhD Candidate in Law, University of Edinburgh.

* Managing Editor, SCRIPTed. PhD Candidate in Law, University of Edinburgh. 
Another year and another issue published. This issue forms a sort of milestone for the SCRIPTed team as we come to the end of our $11^{\text {th }}$ year of publication, complete our $12^{\text {th }}$ volume and take time to look back at SCRIPTed's past as we simultaneously look towards the changes of the future and where we go with the journal from here. We passed 10 years in publication last December without much of a fanfare to mark our anniversary and wished to rectify that omission with the current issue which features articles and analysis pieces which we believe truly reflect the spirit in which SCRIPTed was created 11 years ago. Indeed this issue started life many months ago now as simply an idea to create a rare dedicated issue, one which would mark the anniversary of the journal as a celebration of its past. Fast forward several months, and much like the journal itself, the concept of this issue has changed from that originally envisaged when we first discussed it and now represents what we believe is more a reflection of where we hope the journal is going in the future both in terms of content and in terms of its ethos. As such, we are dedicating this journal not simply to a look back at our time in publication, but as a look forward to the future, and take this opportunity to celebrate the everchanging research environment from which the journal draws, and the tireless efforts of all those past and present who have been involved in the making of SCRIPTed.

This issue features papers from previous SCRIPTed editors as well as work from early career researchers, a community that SCRIPTed has endeavoured to support, being itself the product of the hard work of many who were, and are currently, beginning their academic careers. The general management and direction of SCRIPTed has always been drawn from within Edinburgh's early career researchers and postgraduate student community, many of whom are or were full and part time PhD candidates (our current management team is no exception). The working of the journal has provided many with invaluable experience in the world of academic publishing and has drawn upon the ever appreciated time and enthusiasm of our student editor volunteers. In this way, the running of the journal itself is something of a teaching exercise for past, current and future students always with the aim of promoting good academic citizenship and creating an inclusive research community. In addition there has always been an emphasis within SCRIPTed in supporting those authors submitting work at the start of their careers and showcasing the high standard of research emerging from this community. This issue is no exception and displays a range of topics across the research spectrum from which SCRIPTed has drawn over the years; from Rachel Hill's look at the problems at the interface between the criminal law and the online world in regards to cyber-misogyny and the rise in revenge porn, through to Nayha Sethi's substantive look at the optimum application of principles and rules for decision-making in healthcare research. They are joined by analysis looking back at the last years of the coalition Government in the UK and their track record in IT law reform, a conceptual examination of "open data", and a look at some of the newest developments in EU data protection. This issue features salient research of the day and marks a continued evolution of the subject areas and the changing features of the research landscape since our inception in 2004.

As research issues have developed, so too has SCRIPTed as a platform for that research with changes to the website completed most recently in 2011. Four years on-line, however, can be a lifetime in terms of the rapidity of change, and with this in mind, and following a determined urge to rejuvenate the journal, this will be the last issue published on the website in its current guise. 
Looking forward, there are many exciting things in store for SCRIPTed. In the coming months we shall be launching a brand new website, with features such as a new, easy to use interface, and social media integration. In the coming year we also hope to publish a student blog, where students or researchers at any stage in their academic career can explore early-stage ideas on the SCRIPTed website.

At SCRIPTed we draw on a thriving academic community of young legal researchers, from Masters students through to $\mathrm{PhD}$ candidates and of course our Advisory Board of experts to facilitate the running of the journal. This coming year will also see some changes to our Editorial Board. This marks the last issue with Laura Downey as Editor in Chief who is stepping down this year. Catriona McMillan, our current Managing Editor will be taking over the role of Editor in Chief and we are pleased to welcome our new Managing Editor, Edward Dove, $\mathrm{PhD}$ Candidate; and social media editor, Laurence Diver, $\mathrm{PhD}$ Candidate, who will be taking on this role in addition to his responsibilities as Technical Editor. We would also like to welcome our new student editors; Masters and PhD candidates at Edinburgh Law School.

Despite plans for forthcoming changes, SCRIPTed shall remain, as ever, a high quality online journal, with a commitment to supporting early career researchers in the field of law, from those who work at the journal itself in gaining valuable editorial experience, to those who submit pieces for publication. All of our publications shall of course also continue to be open access, released under a Creative Commons licence, in the name of accessibility of scholarship to the widest possible audience. We are proud of our rigorous review process, and this, among other aspects of the journal, shall remain the same as we move into a new era.

We would like to thank everyone who has been involved in this special issue of SCRIPTed for their contributions, and also those who have been involved throughout the lifetime of the journal. Looking forward to a new beginning, and continuing to work with academics, familiar, and new, we wish everyone a happy holiday, and very best wishes for the New Year. 